\title{
Two-Stage Production System Pondering upon Corporate Social Responsibility in Food Supply Chain: A Case Study
}

\author{
Ten-Suz Chen ${ }^{1}$, Yung-Fu Huang ${ }^{2}\left(\mathbb{D}\right.$, , Ming-Wei Weng $^{2}$ and Manh-Hoang Do $2,3, * \mathbb{C}$ \\ 1 Department of Business Administration, Chaoyang University of Technology, Taichung 41349, Taiwan; \\ s10837906@cyut.edu.tw \\ 2 Department of Marketing and Logistics Management, Chaoyang University of Technology, Taichung 41349, \\ Taiwan; huf@cyut.edu.tw (Y.-F.H.); mwweng@cyut.edu.tw (M.-W.W.) \\ 3 Faculty of Economics, Tay Nguyen University, Buon Ma Thuot 63000, Vietnam \\ * Correspondence: s10537912@gm.cyut.edu.tw; Tel.: +886-4-2332-3000
}

check for updates

Citation: Chen, T.-S.; Huang, Y.-F.; Weng, M.-W.; Do, M.-H. Two-Stage Production System Pondering upon Corporate Social Responsibility in Food Supply Chain: A Case Study. Appl. Sci. 2021, 11, 1088. https:// doi.org/10.3390/app11031088

\section{Academic Editor:}

Theodoros Varzakas

Received: 24 December 2020

Accepted: 21 January 2021

Published: 25 January 2021

Publisher's Note: MDPI stays neutral with regard to jurisdictional claims in published maps and institutional affiliations.

Copyright: (c) 2021 by the authors Licensee MDPI, Basel, Switzerland. This article is an open access article distributed under the terms and conditions of the Creative Commons Attribution (CC BY) license (https:// creativecommons.org/licenses/by/ $4.0 /)$

\begin{abstract}
Corporate social responsibility (CSR) has witnessed remarkable attention in academic studies as well as being widely conducted in different industries globally. This specific case was chosen as one of the biggest dairy companies that may be represented for Vietnam dairy supply chain management. This research aims to integrate CSR initiatives into food supply chain management to clarify the optimal replenishment policy, paying close attention to the relationship between midstream manufacturers and final customers. The classical economic production quantity model has been employed, relying on the two-stage assembly production system. The three parameters that contribute to the total profit formulation that have been considered consist of the social charity amount for per unit selling, the unit wholesale price of the manufacturer, and the return rate of used goods from the customer. The study has stressed that there is a significant impact from implementing CSR initiatives on the enterprise's inventory policy that leads to enhance the firm's financial performance.
\end{abstract}

Keywords: Two-stage production system; corporate social responsibility; supply chain; dairy industry; social charity; Vietnam

\section{Introduction}

The idea of conducting corporate social responsibility (CSR) has undergone phenomenal growth in recent decades and has been rolled out in diverse sectors globally, such as the European banking industry [1], Vietnamese coffee sector [2], Jordanian pharmaceutical industry [3], the U.S. restaurant industries [4], Chinese food industry [5], and so on. Indeed, this positive signal has attracted increasing interest from corporations due to the advantages of adopting CSR into their business strategy [6-8]. Some recent studies have stated the critical role of CSR activities; for example, the positive effects of CSR on the firm's financial performance $[9,10]$, the value perception by consumers is generated [11], corporate reputation, consumer's satisfaction, or competitive advantage of the company [12-14]. Thus, two major characteristics contribute to CSR simply understanding as follows: firstly, the relationship between corporate responsibility and the firm's stakeholders, including internal and external. Secondly, toward sustainable development, which obligation has divided into three major issues: enhancing the economy, protecting the environment, and contributing to local society. Hence, CSR initiatives have been conducted and considered an excellent tool to attain sustainability [15-17].

In terms of supply chain management (SCM), the structure starts from the first stage known as upstream suppliers to the last step known as downstream customers; thus, there are many relationships among stakeholders in the supply chain that must be solved and predicted [18-20]. Additionally, the positive signal from CSR initiatives can enhance SCM 
performance and may obtain a sustainable supply chain; thus, the number of studies integrating CSR initiatives into SCM has also been gradually becoming popular and diverse in many different industries worldwide $[14,21,22]$. Hence, adopting CSR initiatives into SCM may have been affected by various factors or barriers $[18,19]$. The customer is at the last stage of the supply chain but also plays a decisive role in the sales of products and impacts the economic responsibility of the firms. However, there are only a few studies concerning the relationship between customers and manufacturers, which have an influence on CSR ideas, especially the food supply chain $[16,17]$. The food supply chain has several particular characteristics compared to other sectors; thereby, research integration of CSR initiatives into the food SCM is attaining much attention due to its contribution to sustainability, particularly in transitional economies [23]. From some of the existing CSR-SCM studies about stakeholder theory, they have demonstrated that businesses' efforts to adopt CSR activities into corporate governance policies to satisfy the interests of shareholders and stakeholders because SCM plays a role as the critical interface with suppliers or agency services, for instance, logistics services, transport providers, service of yards and warehouses $[24,25]$. Unfortunately, only a few studies consider the optimal model related to SCM stakeholders; meanwhile, the excellent role of CSR programs in SCM sustainability has not been considered properly, particularly in transitional economies [21,22]. Thus, this research aims to propose an optimal model for the food supply chain, which can adopt CSR initiatives into the food SCM. In this way, supporting the food company has a social contribution as well as obtaining superior financial performance. This study has some research questions as follows:

$R Q 1$. What is the optimal social charity amount for per unit product selling?

$R Q 2$. What is the optimal production run time of the manufacturer?

$R Q 3$. What is the optimal return rate of used products from the customer?

This study makes several contributions to the published literature regarding CSR and SCM. Firstly, this research develops the classical economic production quantity (EPQ) model to address the stakeholders' satisfaction under the two-stage assembly production system. An analysis between two supply chain members will be conducted, including midstream manufacturers and downstream buyers, whose members are witnessing the CSR adoption. Secondly, the proposed EPQ model's efficacy has been assessed through the Vietnamese dairy supply chain case study, which is among the critical sectors contributing to the sustainable development of a developing nation like Vietnam [26]. This is the unique research considering the relationship between CSR practices and food supply chain management in Vietnam; thus, the research findings provide useful information to SCM's managers. Moreover, this model's scope can also be expanded to various sectors to determine the proposed model's efficacy. The structure of this study as follows. The authors discussed the introduction in Section 1. The literature review and the methodology of this study will be described in Sections 2 and 3, respectively. The next section will outline the notation and model formulation for this research. A numerical example of this study will be shown in Sections 5 and 6 . In the last part, Section 7 outlines the research implications and limitations of the study, as well as suggestions for new study directions in the future.

\section{Literature Review}

To date, the definition of CSR is still controversial about consistency, and there are many different perspectives on CSR definition [7,11]. In studies of the stakeholders' theory, the scholars agreed that businesses would enhance their profit; however, they must also assume responsibilities to the environment, community, and society where the company is operating [27]. Therefore, the CSR concept has been understood under three responsibilities dimensions: economic, social, and environmental responsibility [2,27]. Regarding supply chain management, this includes many different stages with several complex relationships between the company and other stakeholders. The role of stakeholders in sustainable supply chain management (SSCM) has been described in several previous studies, such as empirical research in India of Das (2018) [12]; a review research from Sodhi 
and Tang (2018) [18]; or Sarkar et al. (2018) who suggested a production model of the automobile SSCM related to environment protection [20]. Consequently, corporatations need to determine their responsibilities with goods from the first stage as forming ideas [28]. CSR initiatives have been employed as useful tools to incorporate with SCM to improve corporate decision-making effectiveness, as well as to accomplish SSCM targets [21,24,29]. In fact, the findings obtained have recently shown that various studies incorporating CSR and SCM have been increasing rapidly. For instance, Feng (2017) systematically reviewed the relationship between CSR and SCM among previous studies and pointed out that these studies are heavily concentrated in developed countries; meanwhile, just a few studies have been conducted in emerging economies [21]; Das (2018) evaluated the model to enhance SSCM performance of the Indian enterprises through competitiveness measurement that had been influenced by CSR practices [12]; Khalid et al. (2015) suggested employing threeaspect obligations to attain SSCM, however, they found a lack of attention on the social dimension of the SCM compared to other responsibilities [30]; Wu et al. (2017) indicated that supplier's CSR misconduct directly remarkably affects the economic performance in the SCM [25].

In terms of the food supply chain sector, which is always a difference between the food industry and other industries since the characteristics of food products such as food quality, safety, storage condition, and shelf life as well as the process of transporting between warehouses, and stores to end customers [5,31]. These are factors that can easily occur in incidents related to food goods. Moreover, it also may impact food supply chain management and make them more difficult and complicated, although the companies have applied risk mitigation strategies in the supply chain [5,31,32]. Evaluation of the correlation between CSR issues and the food SCM has been indicated as a hot topic and given much attention by some scholars in recent years [21]. For instance, Chkanikova and Mont (2015) highlighted some drivers and barriers for food retailers in conducting CSR in their supply chains [33]; Prakash (2018) indicated the rise of CSR and SCM studies; however, it is not really significant and worthy of research potential [34]. Hence, there has been a gap in sustainability efforts and outcomes between developed nations and emerging nations in attaining a sustainable food supply chain. The comparison research between two types of countries has been conducted and claims that in developed countries' conditions where mature supply chains already exist, the industry can adopt risk mitigation strategies and achieve the effectiveness. They also suggested that the future of research should clarify which conditions in transitional economies are needed to achieve a sustainable supply chain [35]. However, their similar findings suggested that companies should pay attention to the different stages and their roles from up-stream to down-stream $[28,36]$.

Regarding SCM in the developing country context, especially in the perishable food supply chain, no company wants to suffer the risk of damage because of perishable products such as meat, seafood, or other perishable goods. The relationship between manufacturers and retailers is very complicated and mainly focused on their economic benefits. There are two aspects, including the price markdown costs and it is related to some parameters such as potential customer quantity and market price fluctuations. These two factors affect the optimal choice of pricing strategy of the enterprises in the perishable food supply chain [37]. Meanwhile, the perceived consumer in developing countries has changed significantly in recent years. Huang et al. (2019) stressed that Vietnamese consumers have more interest and are willing to spend more money on products from socially responsible companies [11]. In terms of the dairy SCM, the dairy quality was the top priority of all stakeholders as well as stages in the SCM; thus, the biggest issue is dairy quality assurance across the entire supply chain because the specificity of dairy products is highly perishable and it is very costly to preserve refrigeration and collect it continuously. Previous studies have shown that manufacturers and stakeholders such as farmers, logistic services, and suppliers have mutual responsibility related to dairy quality [23,38-41]. Hence, studying the optimal model of integrating CSR into SCM in the food industry context will enrich the CSR and SCM literature and suggest more new promising ideas for other scholars in the future. 


\section{The Research Methodology}

\subsection{The EPQ Model}

The classical economic production quantity model is developed based on the single product and single-stage production system; furthermore, it has been widely employed in various SCM studies [42-45]. In fact, the manufacturing process's complexity recently has witnessed more involvement with different components, from raw materials procurement to distribution systems for finished products. Therefore, several articles have been interested in studying how the end product is manufactured through a multi-stage production system [46-48]. Several studies have noted that multi-component production strategies adopt opportunistic maintenance policies [49-52]. However, only a little literature has been published on the impact of CSR in the inventory field. Those recommendations have mentioned that the impact of CSR on the manufacturing process as well as the supply chain would be given new opportunities to explore. For instance, Modak et al. (2019) have considered the effect of selling price and social work donation on demand for three-channel structures [53].

The authors will illustrate the optimal model to enrich the findings of Chang et al. (2012), who have conducted that model in the automation industry. They have also suggested that other scholars may evaluate their model in various industries or another country context [47]. Consequently, many scholars have been conducting the two-stage production system approach to point out the most suitable EPQ model for their examples. This example can be demonstrated by Gupta and Mohanty (2015), Dey et al. (2019), or Sabbaghnia and Taleizadeh (2020); they have argued the two-stage production system perspective through their research $[48,54,55]$, particularly SCM integration with CSR similarly to Nematollahi et al. (2017), and Jokar and Hosseini-Motlagh $(2020)$ [56,57]. Furthermore, they have recommended evaluating this approach's applicability to different sectors in the real world. From these suggestions include relying on different characteristics related to the dairy industry and the emerging economy; thus, the author has employed the proposed model of Chang et al. (2012) to evaluate concordance through a case study in the Vietnamese dairy industry. Moreover, it has also contributed to filling the literature gap in theoretical inventory management in the dairy supply chain.

\subsection{The Research Context}

Vietnam is a transitional economy with agriculture as a majority development sector $[58,59]$. The Vietnamese dairy industry is one of the priority sectors for sustainable development targets and receives attention from government policies and enterprises, and the community [26]; furthermore, the Vietnamese dairy industry represents a typical case study in the Vietnamese supply chain (be presented in Figure 1). However, only a few dairy firms are involved in CSR programs and attempt to commit to stakeholders, the community, and society. Hence, their CSR programs' undeniable efforts over the years related to shareholders, employees, local-residents, environment protection, and others, have had a phenomenal contribution to the sustainability of a transitional economy like Vietnam [11]. Furthermore, the perception of Vietnamese consumers for products is also increased when they pay more attention to the origin of the products as well as the responsibilities of those companies to society instead of only being interested in price and quality [11]; therefore, it has given a positive sign and become the dynamic for Vietnamese dairy firms to CSR adoption. 


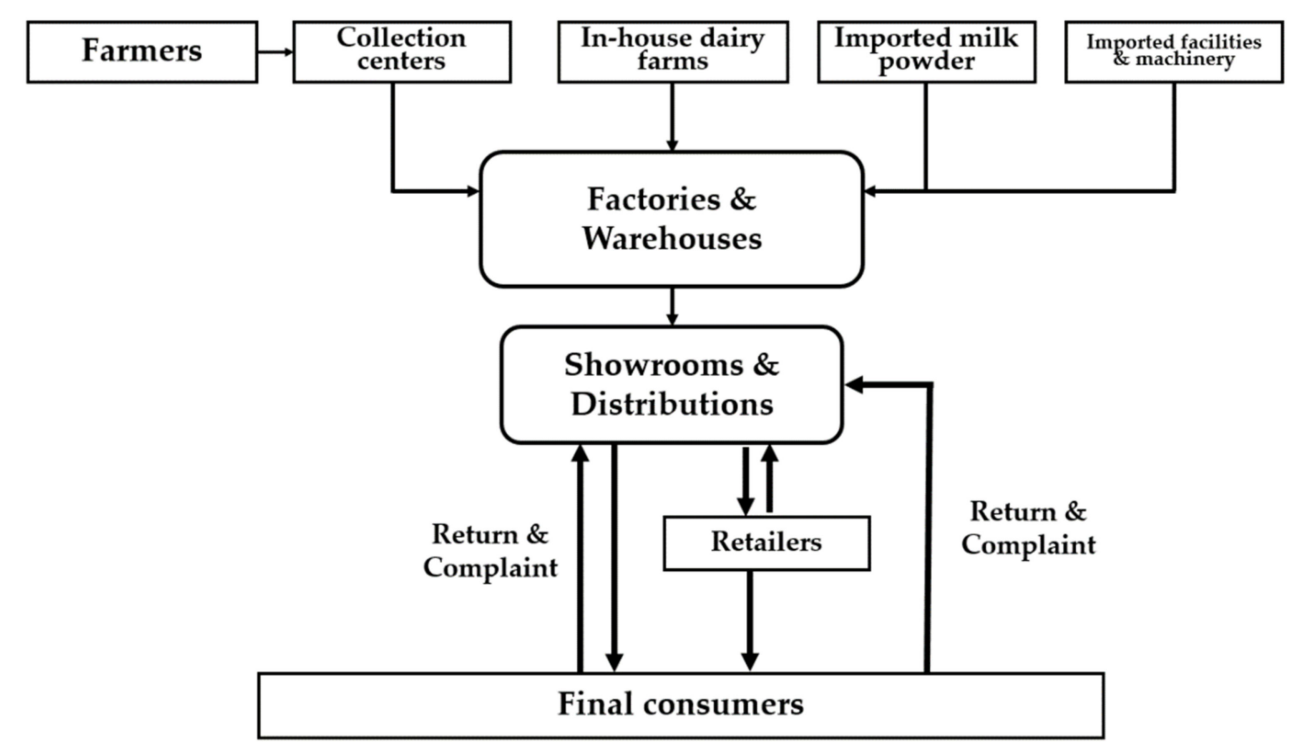

Figure 1. Simplified Vietnam's Dairy Supply Chain. (Source: The authors).

\section{Model Formulation}

\subsection{Notation}

In this study, the authors proposed an EPQ model for a two-stage assembly production system throughout one cycle. The system illustrates the relationship for all returned products in Stage 1 (manufacturing process) and end product in Stage 2 (assembly process). The manufacturer also directly collects the returned goods through a closed-loop supply chain with a reverse dual-channel. To ease readability, the authors will adopt the same notation in the production system and formulation from Chang et al. (2012) for this paper. The notation used in this paper, including system parameters and decision variables, has been listed in Tables 1 and 2, respectively.

Table 1. System parameters of this study.

\begin{tabular}{cl}
\hline$m$ & The number of return points at retailer stage. \\
$n$ & The number of raw material sourcing at the manufacturing stage. \\
$p_{i}$ & Production rate of the return source $i$ at retailer stage, where $i=1,2, \ldots, n$ and $p_{1}>p_{2}>\ldots>p_{n}$ \\
$D$ & Demand rate. \\
$k$ & Setup cost. \\
$c_{1}$ & The unit price of a returned product that the manufacturer paid to the customer. \\
$c_{0}$ & The unit cost of the manufacturer paid to customers for a returned unit. \\
$r$ & The return rate of used goods from the customer $(0 \leq \mathrm{r} \leq 1)$ \\
$h_{i}$ & Holding cost of the source $i$ for raw materials at the manufacturer stage, with $i=1,2, \ldots, n$. \\
$h_{e}$ & Holding cost of an end product at retailer stage. \\
$\theta_{i}$ & The defective rate of the source $i$ for raw material at the manufacturer stage, with $i=1,2, \ldots, n$. \\
$\theta_{e}$ & The defective rate of an end product at retailer stage. \\
$d_{i}$ & Disposal cost for a defective source $i$ for raw materials at the manufacturer stage, with $i=1,2, \ldots, n$. \\
$d_{e}$ & Disposal cost for a defective end product at retailer stage. \\
$d_{r e}$ & Disposal cost for a returned product at retailer stage. \\
$t_{i d}$ & The time period when the inventory of source $i$ for raw materials depletes, with $i=1,2, \ldots, n$. \\
$t_{r d i}$ & Return period for an inventory of the used product at i retailer, with $i=1,2, \ldots, m$. \\
$I_{r}$ & Investment in collection activities at the retailer stage. \\
$I_{s}$ & Investment in CSR activity at the manufacturing stage. \\
$T_{1}$ & The amount of cycle time. \\
$Z_{i}$ & The maximum inventory level of source $i$ for raw material at the manufacturer stage, with $i=1,2, \ldots$ \\
$Z_{e}$ & The maximum inventory level of the end product at the retailer stage. \\
$Z_{r e}$ & The maximum inventory level of the returned product at the retailer stage. \\
$p_{w}$ & The unit wholesale price of the manufacturer. \\
\end{tabular}


Table 2. Decision variables.

\subsection{Assumptions}

The aim is to determine the effects of an optimal model for this study, therefore, the authors have adopted four assumptions as below.

(1) The production cycle repeats infinitely.

(2) Following the line of Savaskan et al. (2004), the total collection cost : $C(r)=$ $I_{r}+c_{0} r D=\alpha r^{2}+c_{0} r D$, where $r D$ was the total amount of goods which will be returned from customers; besides, $D=a-b p_{w}+\delta s$; moreover, $a>0$, is the entire size of the market, $b$ is the price sensitivity of demand, $\delta$ is the social charity of demand.

(3) The return rate for used products from the customers to the manufacturer in the reverse channel, where $r=\sqrt{I_{r} / \alpha}$ and $\alpha$ is a scaling parameter.

(4) Based on Ma et al. (2013) and Hosseini-Motlagh et al. (2018), MI is the investment function of the manufacturer which is illustrated as follows $M I=\sqrt{I_{S} / \varepsilon}$, where $\varepsilon$ is a scaling parameter $[46,60]$.

(5) The authors consider forward and reverse dual-channel in reverse logistics with a manufacturer and a retailer. In the forward dual-channel, the manufacturer sells a product on the market through the retailer through reverse logistics. In reverse dualchannel, the manufacturer collects the returned products; additionally, they also conduct CSR activities.

\subsection{Model Formulation}

From the notation and assumptions illustrated above, the graph of production system during the time period from 0 to $\mathrm{T}[0, \mathrm{~T}]$ will be demonstrated in the two-stage production system (reference in Figure A1 of Appendix A). The total profit function will be established; the model of research is a perfect cyclic process. The demands of customers with amounts of dairy products in a cycle will be met by the right number of goods from manufacturers (i.e., $p_{i} t_{i}=p_{n} t_{n}=D T$ ).

Therefore, $t_{i}$ and $T$ can be presented in turn as follows:

$$
t_{i}=\frac{p_{n} t_{n}}{p_{i}}
$$

with $i=1,2, \ldots, n$ and

$$
T=\frac{p_{n} t_{n}}{D},
$$

Hence, the maximum level of inventory for raw material $i$ at retailer stage is

$$
Z_{i}=\left(p_{i}-p_{e}\right) t_{i}
$$

with $i=1,2, \ldots, n$.

Therefore, the period when the inventory of raw material $i$ depletes can be determined as:

$$
t_{i d}=\frac{Z_{i}}{p_{e}}=\frac{\left(p_{i}-p_{e}\right) t_{i}}{p_{e}}=\left(\frac{p_{i}}{p_{e}}-1\right) t_{i}
$$

with $i=1,2, \ldots, n$. 


$$
\begin{gathered}
H_{e}=\left(p_{e}-D\right)\left(t_{n}+t_{n d}\right) \\
=\left(p_{e}-D\right)\left[t_{n}+\left(\frac{p_{n}}{p_{e}}-1\right) t_{n}\right] \\
=\left(p_{e}-D\right) \frac{p_{n}}{p_{e}} t_{n} .
\end{gathered}
$$

However, the maximum inventory level of return used product as

$$
Z_{r e}=r t_{r d i}
$$

where $i=1,2, \ldots, m$.

Based on six Equations (1)-(6), with the influence of these components, the total profit function will be established as follows:

(1) Sales revenue $(S R)$

$$
S R=\left(p_{w}-s\right)
$$

(2) Setup cost

$$
C_{s}=k
$$

(3) Holding the cost of the end product $\left(H C_{e}\right)$

$$
H C_{e}=\frac{h_{e} Z_{e} T}{2}=\frac{h_{e}\left(p_{e}-D\right)}{2 D p_{e}} p_{n}{ }^{2} t_{n}{ }^{2}
$$

(4) Holding the cost of all materials $\left(H C_{c}\right)$

$$
H C_{c}=\frac{p_{n}^{2} t_{n}^{2}}{2}\left[\sum_{i=1}^{n} h_{i}\left(\frac{1}{p_{e}}-\frac{1}{p_{i}}\right)\right]
$$

(5) Disposal costs of the defective end product/all raw materials per cycle (DC)

$$
D C=\left(d_{e} \theta_{e}+\sum_{i=1}^{n} d_{i} \theta_{i}\right) D T+\left(T-\sum_{i=1}^{m} t_{r d i}\right) r d_{r e}
$$

(6) Return costs for used products at retailer stage $(R C)$.

$$
R C=c_{1} r \sum_{i=1}^{m} t_{r d i}
$$

(7) Based on Giri's proposed model in 2005 [61], the production cost (PC) as:

$$
P C=\left(\beta_{0}+\frac{\beta_{1}}{p_{e}}+\beta_{2} p_{e}\right) p_{n} t_{n} .
$$

In the integrated supply chain system, all upstream manufacturers are willing to conglomerate resources. In an organizational decision-making process involving the manufacturer and the retailer, a product is manufactured in a single batch. Thus, making capital investment decisions on CSR activities is given by $I_{S}$ and collecting the used products for recycling is given by $I_{r}$. Based on Savaskan et al. (2004), both investment costs are $I_{s}=\beta s^{2}$ and $I_{r}=\alpha r^{2}$, where $\alpha$ and $\beta$ are scaling parameters, respectively [62]. Therefore, the objective function of the proposed model consisting of seven parts to maximize the total profit per unit of time is given by optimizing $s, t_{n}$, and $r$. 
Thus, the total profit per unit time (denoted by $T P\left(s, t_{n}, r\right)$ ) is given by

$$
\begin{aligned}
T P\left(s, t_{n}, r\right)= & \left(S R-S C-H C_{e}-H C_{c}-D C-R C-P C\right) \\
= & \left(p_{w}-s+c_{1} r\right)\left(a-b p_{w}+\delta s\right) \\
& -\left[\frac{h_{e}\left[p_{e}-\left(a-b p_{w}+\delta s\right)\right]}{\left(a-b p_{w}+\delta s\right) p_{e}}+\left[\sum_{i=1}^{n} h_{i}\left(\frac{1}{p_{e}}-\frac{1}{p_{i}}\right)\right]\right] \frac{p_{n}^{2} t_{n}^{2}}{2} \\
& -\left[\left(d_{e} \theta_{e}+\sum_{i=1}^{n} d_{i} \theta_{i}\right)+\left(\beta_{0}+\frac{\beta_{1}}{p_{e}}+\beta_{2} p_{e}\right)+\frac{r d_{r e}}{a-b p_{w}+\delta s}\right] p_{n} t_{n} \\
& +\left(d_{r e}-c_{1}\right) r \sum_{i=1}^{m} t_{r d i} \\
& -\beta s^{2}-\alpha r^{2}-k .
\end{aligned}
$$

Aiming to address this nonlinear programming issue, the authors first ignore the restriction and take the first-order derivation of $T P\left(s, t_{n}, r\right)$ with respect to $s, t_{n}, r$, respectively. We obtain

$$
\begin{gathered}
\frac{\partial T P\left(s, t_{n}, r\right)}{\partial s}=\left[\delta c_{1} r+(b-\beta) p_{w}+(\beta+\delta)\left(p_{w}-2 s\right)-a\right] \\
-\left(p_{n} t_{n} h_{e}+2 r d_{r e}\right)\left[\frac{\delta}{\left(a-b p_{w}+\delta s\right)^{2}}\right] \frac{p_{n} t_{n}}{2}, \\
\frac{\partial T P\left(s, t_{n}, r\right)}{\partial t_{n}}=-\left\{\frac{h_{e}\left[p_{e}-\left(a-b p_{w}+\delta s\right)\right]}{\left(a-b p_{w}+\delta s\right) p_{e}}+\left[\sum_{i=1}^{n} h_{i}\left(\frac{1}{p_{e}}-\frac{1}{p_{i}}\right)\right]\right\} p_{n}{ }^{2} t_{n} \\
-\left[\left(d_{e} \theta_{e}+\sum_{i=1}^{n} d_{i} \theta_{i}\right)+\left(\beta_{0}+\frac{\beta_{1}}{p_{e}}+\beta_{2} p_{e}\right)+\frac{r d_{r e}}{a-b p_{w}+\delta s}\right] p_{n},
\end{gathered}
$$

and

$$
\frac{\partial T P\left(s, t_{n}, r\right)}{\partial r}=c_{1}\left(a-b p_{w}+\delta s\right)+\left(d_{r e}-c_{1}\right) \sum_{i=1}^{m} t_{r d i}-2 \alpha r .
$$

To find the optimal solution of $\left(s, t_{n}, r\right)$, let $\partial T P\left(s, t_{n}, r\right) / \partial s=0, \partial T P\left(s, t_{n}, r\right) / \partial t_{n}=0$, and $\partial \operatorname{TP}\left(s, t_{n}, r\right) / \partial r=0$, simultaneously. Solving these three equations, we obtain

$$
\begin{aligned}
& \delta c_{1} r+(b+\delta) p_{w}=\left[\frac{p_{n} t_{n} h_{e}+2 r d_{r e}}{2\left(a-b p_{w}+\delta s\right)^{2}}\right] \delta p_{n} t_{n}+a+2 s(\delta+\beta), \\
& \left\{\frac{h_{e}\left[p_{e}-\left(a-b p_{w}+\delta s\right)\right]}{\left(a-b p_{w}+\delta s\right) p_{e}}+\left[\sum_{i=1}^{n} h_{i}\left(\frac{1}{p_{e}}-\frac{1}{p_{i}}\right)\right]\right\} p_{n}{ }^{2} t_{n}+\frac{r d_{r e}}{a-b p_{w}+\delta s} p_{n} \\
& =-\left[\left(d_{e} \theta_{e}+\sum_{i=1}^{n} d_{i} \theta_{i}\right)-\left(\beta_{0}+\frac{\beta_{1}}{p_{e}}+\beta_{2} p_{e}\right)\right] p_{n},
\end{aligned}
$$

and

$$
r=\frac{c_{1}\left(a-b p_{w}+\delta s\right)+\left(d_{r e}-c_{1}\right) \sum_{i=1}^{m} t_{r d i}}{2 \alpha} .
$$

From Equations (11)-(13), it is clear that $s$ and $r$ can be uniquely determined as functions of $t_{n}$. To analyze the inventory problem, we will show that for any given feasible $\left(s^{*}, r^{*}\right)$, the optimal production run time also exists and is unique. For given $s^{*}$ and $r^{*}$, the first-order necessary condition for $\operatorname{TP}\left(t_{n} \mid s^{*}, r^{*}\right)$ to be maximum is 


$$
\begin{aligned}
\frac{d T P\left(t_{n} \mid s^{*}, r^{*}\right)}{d t_{n}}= & -\left\{\frac{h_{e}\left[p_{e}-\left(a-b p_{w}+\delta s\right)\right]}{\left(a-b p_{w}+\delta s\right) p_{e}}-\left[\sum_{i=1}^{n} h_{i}\left(\frac{1}{p_{e}}-\frac{1}{p_{i}}\right)\right]\right\} p_{n}{ }^{2} t_{n} \\
& -\left[\left(d_{e} \theta_{e}+\sum_{i=1}^{n} d_{i} \theta_{i}\right)+\left(\beta_{0}+\frac{\beta_{1}}{p_{e}}+\beta_{2} p_{e}\right)+\frac{r d_{r e}}{a-b p_{w}+\delta s}\right] p_{n} \\
= & 0 .
\end{aligned}
$$

Let $G\left(t_{n}\right)$ be the left-hand side of Equation (14), i.e.,

$$
\begin{aligned}
G\left(t_{n}\right)= & -\left\{\frac{h_{e}\left[p_{e}-\left(a-b p_{w}+\delta s^{*}\right)\right]}{\left(a-b p_{w}+\delta s^{*}\right) p_{e}}-\left[\sum_{i=1}^{n} h_{i}\left(\frac{1}{p_{e}}-\frac{1}{p_{i}}\right)\right]\right\} p_{n}{ }^{2} t_{n} \\
& -\left[\left(d_{e} \theta_{e}+\sum_{i=1}^{n} d_{i} \theta_{i}\right)+\left(\beta_{0}+\frac{\beta_{1}}{p_{e}}+\beta_{2} p_{e}\right)+\frac{r^{*} d_{r e}}{a-b p_{w}+\delta s^{*}}\right] p_{n} .
\end{aligned}
$$

We first rewrite Equation (14) and have

$$
\begin{aligned}
& {\left[\left(d_{e} \theta_{e}+\sum_{i=1}^{n} d_{i} \theta_{i}\right)+\left(\beta_{0}+\frac{\beta_{1}}{p_{e}}+\beta_{2} p_{e}\right)+\frac{r^{*} d_{r e}}{a-b p_{w}+\delta s^{*}}\right] p_{n}} \\
& =-\left\{\frac{h_{e}\left[p_{e}-\left(a-b p_{w}+\delta s^{*}\right)\right]}{p_{e}\left(a-b p_{w}+\delta s^{*}\right)}-\left[\sum_{i=1}^{n} h_{i}\left(\frac{1}{p_{e}}-\frac{1}{p_{i}}\right)\right]\right\} p_{n}{ }^{2} t_{n} .
\end{aligned}
$$

Because of the left-hand side of Equation (16)

$$
\left[\left(d_{e} \theta_{e}+\sum_{i=1}^{n} d_{i} \theta_{i}\right)+\left(\beta_{0}+\frac{\beta_{1}}{p_{e}}+\beta_{2} p_{e}\right)+\frac{r^{*} d_{r e}}{a-b p_{w}+\delta s^{*}}\right] p_{n}>0,
$$

then we have $\Delta>0$, where

$$
\Delta \equiv\left\{\left[\sum_{i=1}^{n} h_{i}\left(\frac{1}{p_{e}}-\frac{1}{p_{i}}\right)\right]-\frac{h_{e}\left[p_{e}-\left(a-b p_{w}+\delta s^{*}\right)\right]}{p_{e}\left(a-b p_{w}+\delta s^{*}\right)}\right\} p_{n}{ }^{2} t_{n} .
$$

Next, taking the first-order derivative of $G\left(t_{n}\right)$ with respect to $t_{n}$, we obtain

$$
\frac{d G\left(t_{n}\right)}{d t_{n}}=\left\{\left[\sum_{i=1}^{n} h_{i}\left(\frac{1}{p_{e}}-\frac{1}{p_{i}}\right)\right]-\frac{h_{e}\left[p_{e}-\left(a-b p_{w}+\delta s^{*}\right)\right]}{\left(a-b p_{w}+\delta s^{*}\right) p_{e}}\right\} p_{n}^{2}=\frac{\Delta}{t_{n}}>0 .
$$

Therefore, $G\left(t_{n}\right)$ is a strictly increasing function $t_{n} \in(0, \infty)$.

Theorem 1. For any given $t_{n} \geq 0$, we consider the interval $t_{n} \in(0, \infty)$,

(a) If $G\left(t_{n}\right)<0$, then the solution $\left(s^{*}, t_{n}^{*}, r^{*}\right)$ which maximizes $T P\left(s, t_{n}, r\right)$ not only exists but also is unique, and $t_{n}^{*} \in(0, \infty)$.

(b) If $G\left(t_{n}\right) \geq 0$, then the optimal value of $t_{n}$ is $t_{n}^{*} \rightarrow 0$. The production system should not be opened.

\section{Proof.}

(a) Firstly, we consider the interval $t_{n} \in(0, \infty)$. Because $\lim _{t_{n} \rightarrow \infty} G\left(t_{n}\right)=\infty$ and $\lim _{t_{n} \rightarrow 0} G\left(t_{n}\right)<0$, from the Intermediate Value Theorem, we can find a unique solution $t_{n}^{*} \in(0, \infty)$ such that $G\left(t_{n}^{*}\right)=0$. Substituting $t_{n}^{*}$ into Equations (8)-(10), the corresponding $s^{*}$ and $r^{*}$ can be determined. Furthermore, we also calculate that

$$
\mathbf{H}_{11}=\left.\frac{\partial^{2} T P\left(s, r \mid t_{n}\right)}{\partial s^{2}}\right|_{(s, r)=\left(s^{*}, r^{*}\right)}=2\left\{\left[\frac{\delta^{2} p_{n} t_{n}\left(h_{e} p_{n} t_{n}+r d_{r e}\right)}{\left(a-b p_{w}+\delta s\right)^{3}}\right]-(\beta+\delta)\right\},
$$




$$
\mathbf{H}_{22}=\left.\frac{\partial^{2} T P\left(s, r \mid t_{n}\right)}{\partial r^{2}}\right|_{(s, r)=\left(s^{*}, r^{*}\right)}=-2 \alpha<0,
$$

and

$$
\mathbf{H}_{12}=\mathbf{H}_{21}=\left.\frac{\partial^{2} T P\left(s, r \mid t_{n}\right)}{\partial s \partial r}\right|_{(s, r)=\left(s^{*}, r^{*}\right)}=0 .
$$

Therefore, the determinant of the Hessian matrix at the stationary point $\left(s^{*}, r^{*}\right)$ is

$$
\begin{aligned}
\operatorname{det}(H) & =\mathbf{H}_{11} \times \mathbf{H}_{22}-\mathbf{H}_{12} \times \mathbf{H}_{21} \\
& =-4 \alpha\left\{\left[\frac{\delta^{2} p_{n} t_{n}\left(h_{e} p_{n} t_{n}+r d_{r e}\right)}{\left(a-b p_{w w}+\delta s\right)^{3}}\right]-(\beta+\delta)\right\}<0 .
\end{aligned}
$$

(b) From Equation (9), we obtain that $\frac{\partial T P\left(s, t_{n}, r\right)}{\partial t_{n}}<0$, which implies that $t_{n}$ causes a higher value $\operatorname{TP}\left(s, t_{n}, r\right)$. Hence, the maximum value $\operatorname{TP}\left(s, t_{n}, r\right)$ occurs at the point $t_{n}^{*} \rightarrow 0$. It seems reasonable to conclude that the production system will not be opened. This completes the proof.

Summarizing the above results, the Algorithm 1 was used to obtain the optimal solution to our problem.

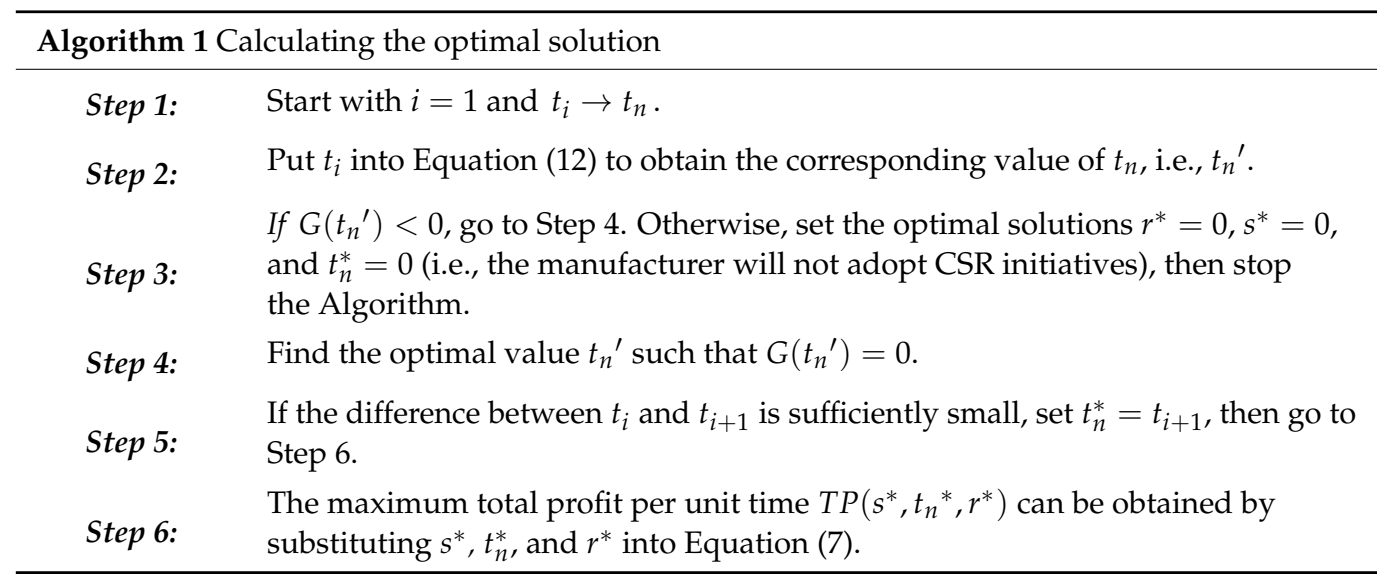

\section{Application Example}

The empirical research context is Vietnam's dairy supply chain to demonstrate the utility and feasibility of the proposed model. ABC dairy corporation was chosen, which is currently the largest dairy company in Vietnam [63]. The ABC company currently has a complete supply chain with several farms, factories, and its own distribution system; moreover, their products have been distributed to nearly all supermarkets and retail points all over Vietnam. Towards sustainable development, ABC dairy firm's orientation would invest heavily in CSR initiatives and be directed to the five major objectives, including community development support; environment and energy; responsibility for employees; responsibility for products; and local economic development. Regarding the ABC dairy company's commitment to the stakeholders, they are committed to providing safe products to consumers with top quality and appropriate prices. Moreover, this company also declares complying with environmental regulations and integrating social responsibility into business strategies. Food products' characteristics are easily broken for many different reasons before reaching customers, combined with the ABC company's product quality assurance policy. Thus, the case study selected as the ABC dairy corporation would help the authors better assess the proposed model in the empirical research.

The authors considered an application example of CSR initiatives to demonstrate the proposed model and verify the obtained analytical results. The real data were collected from $\mathrm{ABC}$ dairy firm and employed for the numerical analysis as following: $k=\$ 80 /$ cycle, $\beta_{0}=0.1, \beta_{1}=0.03, \beta_{2}=0.025, p_{w}=\$ 10, a=15, b=9, \alpha=7, \beta=2, \delta=4$. 
Raw material source 1: $p_{1}=100 /$ per unit time, $h_{1}=\$ 0.01 /$ per unit, $\theta_{1}=0.03$, $d_{1}=\$ 0.01 /$ per unit.

Raw material source 2: $p_{2}=200 /$ per unit time, $h_{2}=\$ 0.02 /$ per unit, $\theta_{2}=0.02$, $d_{2}=\$ 0.02 /$ per unit.

Raw material source 3: $p_{3}=300 /$ per unit time, $h_{3}=\$ 0.375 /$ per unit $/$ per unit time, $\theta_{3}=0.01, d_{3}=\$ 0.03 /$ per unit.

End product in showrooms: $p_{e}=60 /$ per unit time, $h_{e}=\$ 2 /$ per unit $/$ per unit time, $\theta_{e}=0.05, d_{e}=\$ 0.04 /$ per unit.

Then, we find the outcome as $s^{*}=9.58943 ; t_{n}^{*}=0.495389 ; r^{*}=0.0595798$ and $T P\left(s^{*}, t_{n}{ }^{*}, r^{*}\right)=287.392$.

In the finding of this section, the authors evaluate the impact of implementing CSR practices on the company's inventory policy. Thus, the effect of changes in various parameters of the model, for example (in Table A1 of Appendix B), was indicated that the effects of $h_{e}, \beta_{2}$, and $\theta_{e}$ on total profit are significant. These imply that the quality of the end product is essential for the $\mathrm{ABC}$ dairy enterprise.

Thus, maintaining high-quality products secures a high level of demand by end customers whereas poor quality products affect the customer's confidence, reputation, and sales of the company. Aim to create a positive brand image through CSR activities of the enterprise towards the community. Hence, the dairy company was aware of the importance of the public, especially their target customers, having a positive perception of them. As Figure 2 indicated, the concave function of the total economic profit based on per unit time.

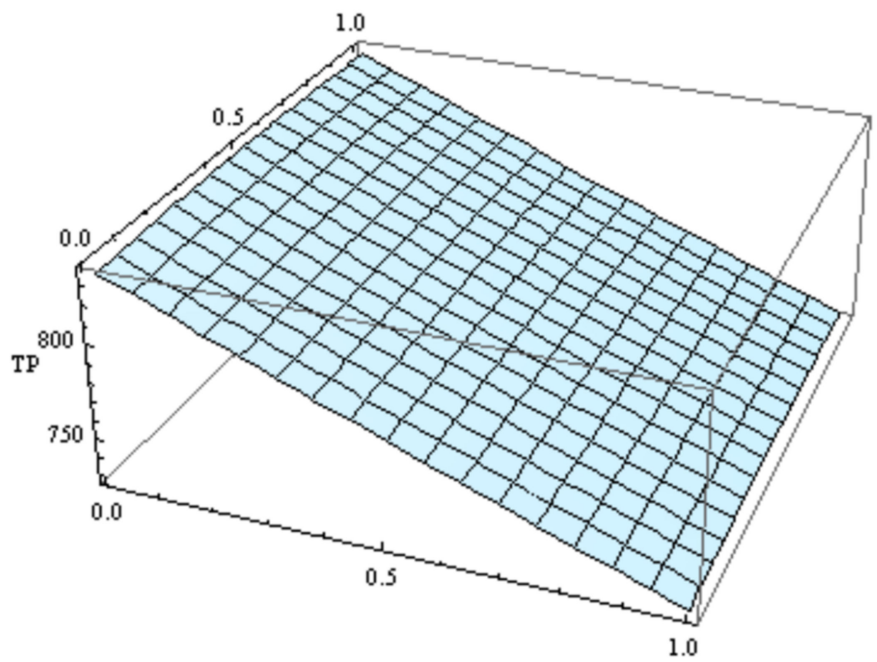

Figure 2. The total profit per unit time $T P\left(s^{*}, t_{n}^{*}, r\right)$ for application example.

\section{Discussion of Research Findings}

Toward sustainable development targets that lead to ABC dairy company's CSR programs being conducted to solve the comprehensive enterprise issue, which has a profitsharing obligation to society beyond making a profit. In fact, to contribute the profit-sharing to the nation's target through charitable activities or community development, the ABC dairy firm has an obligation that implements financial responsibilities before other duties. Therefore, it requires the ABC dairy firm to ensure their accountability to stakeholders, especially shareholders' interests. A numerical example in the above subsection is considered to study the effects of changes in the system parameters $\left(h_{1}, h_{2}, h_{3}, h_{\mathrm{e}}, \theta_{1}, \theta_{2}, \theta_{3}, \theta_{\mathrm{e}}, d_{1}, d_{2}, d_{3}\right.$, $d_{\mathrm{e}}, \beta_{0}, \beta_{1}$, and $\left.\beta_{2}\right)$ on the optimal values of $s^{*}, t_{n}^{*}, r$, and $\operatorname{TP}\left(s^{*}, t_{n}^{*}, r\right)$. The result indicated that the effects of $h_{\mathrm{e}}, \beta_{2}$ and $\theta_{\mathrm{e}}$ on total profit are significant. These imply that the quality of the end product is essential for the $\mathrm{ABC}$ dairy enterprise. Thus, maintaining high-quality products aims to secure a high demand by end customers while struggling with the risk that poor quality products affect customers' confidence, reputation, and sales. Brand image, 
reputation, as well as financial performance can be significantly enhanced through CSR activities of the enterprise towards the community; hence, $\mathrm{ABC}$ dairy company must be aware of the local community's importance, especially their target customers. For the present, it may be useful to look more closely at some of the more important features of the sensitivity analysis performed by changing each of the parameters by $+50 \%,+25 \%$, $-25 \%$, and $-50 \%$; taking one parameter at a time and keeping the remaining parameters unchanged. The analytical results were clearly demonstrated in Table A1 of Appendix B.

From the Table A1 in Appendix B, the following the management implications have been very positive as follows:

(1) When the values of parameters $\left(h_{1}, h_{2}, h_{3}, h_{\mathrm{e}}, \theta_{1}, \theta_{2}, \theta_{3}\right.$ and $\left.\theta_{\mathrm{e}}\right)$ are decreased, it leads to the growth for $T P\left(s^{*}, t_{n}^{*}, r\right)$. It indicates that the firm cooperation with manufacturers is based on these factors, including inventory turnover and the quality of raw material or end products. The total profit has been enhanced, leading to the firm's social donation fund also increasing. Thus, it positively directs on the $\mathrm{ABC}$ dairy enterprise's brand and its reputation from the local community.

(2) With decreases in the value of parameter $\beta_{0}$, then $T P\left(s^{*}, t_{n}^{*}, r\right)$ increases. If the processing cost of raw materials from different sources could be reduced effectively, the total profit would be enhanced. This implies that the ABC dairy firm should invest more in new employee orientation to improve productivity.

(3) With decreases in the value of parameter $\beta_{1}$, then $T P\left(s^{*}, t_{n}^{*}, r\right)$ increases. This implies that the $\mathrm{ABC}$ dairy firm should decrease the labor costs per unit of time (i.e., wage or salary) to increase total profit.

(4) With decreases in the value of parameter $\beta_{2}$, then $\operatorname{TP}\left(s^{*}, t_{n}^{*}, r\right)$ increases. This implies that the $\mathrm{ABC}$ dairy firm should decrease the tool or idle cost per unit of time to increase total profit. Furthermore, the $\beta_{2}$ parameter will have an influence rather than $\beta_{0}$ and $\beta_{1}$ on the total profit per unit time.

(5) With decreases in the value of parameters as $d_{1}, d_{2}, d_{3}$, then $T P\left(s^{*}, t_{n}^{*}, r\right)$ can be increased. This implies that the firm should decrease scrape costs per unit of time to increase total profit.

Apart from complying with laws related to the environment and workers, improving the quality of end products and reducing their holding costs to enhance financial performance are the firms' priority targets. Based on the proposed model of Chang et al. (2012), the authors have developed and evaluated this suggestion to the Vietnamese food supply chain via collected data from the ABC dairy firm case study; thereby, the suitability and positive results have been clarified. These research findings are consistent with other studies related to evaluating the EPQ model under the two-stage assembly production system, such as Dey et al. (2019) and Sabbaghnia and Taleizadeh (2020). They indicated that relationships between SCM members could be comprehensively evaluated to point out the best decision-making; hence, an application example along with sensitivity analysis has been conducted to support this argument. In particular, the relationship between CSR initiatives and SCM of some studies has supported our findings, and the research examples can be seen by Nematollahi et al. (2017); Modak et al. (2019); and Jokar and Hosseini-Motlagh (2020). They have similar conclusions in terms of the vital role as well as the CSR initiatives that could affect decision-making and various SCM performances. Furthermore, to increase donations to local society, the economic performance would be impacted by these activities; however, there is a positive signal from the final customers, whose willingness to buy green products $[11,53]$, or think they are making a small contribution to society generates the enhancing of economic obligation for corporations.

Although the implementation of social activities affects the economic benefits of $A B C$ dairy enterprise, its total profits still increase, which ensures its commitment to its economic responsibility with shareholders and employees. Thus, $\mathrm{ABC}$ dairy corporation is a particular example for the EPQ model's suitability, which can point out some practical implications for the top managers in decision-making related to CSR programs under SCM. They need to establish a risk management mechanism to control any potential risks that 
may affect their operations and profits. With such an arrangement, they can significantly lower the company's operational risk, damage, and impact.

\section{Conclusions}

This study is unique considering integrating CSR initiatives into the food supply chain in Vietnam, which considered some critical decision parameters together and linked the ideas and conclusions based on a particular case study. The noteworthy contributions of Vietnam's dairy firms and their CSR programs are significant to the sustainable development goal of an agricultural country like Vietnam. Aiming to demonstrate the efficiency of the proposed EPQ model, ABC dairy corporation was chosen, which is a typical example that can represent the Vietnam dairy industry in both the main issues of this study as CSR and SCM. Thus, the authors demonstrated the proposed model and clarified how to integrate CSR initiatives into the food SCM. A two-stage assembly production system involving the return rate of used goods from the customer was suggested, which has impacted the CSR policy and top manager decision-making in the dairy supply chain. The research findings are consistent with several prior studies in terms of the CSR initiatives' role, which is considered an excellent tool that may obtain a sustainable supply chain by enhancing social responsibility and the firm's financial performance. Furthermore, total profits per unit of time have been influenced by these critical parameters leading to the following research implications.

(1) Based on theories regarding the relationship between CSR and SCM, these results have contributed to the existing literature on developing the classical economic production quantity model under the two-stage assembly production system.

(2) The findings will help the top managers of dairy corporations in Vietnam better understand the integrating approach and the efficiency of adopting CSR programs into SCM.

(3) The production costs will be effectively controlled, such as material and operating costs. Hence, the firms have more dynamics to devote more money to charitable donations, which positively impacts consumer perception, and then economic performance will be enhanced.

The supply chain management includes all relationships from upstream suppliers to downstream consumers; unfortunately, in this study, the author has just focused on evaluating the relationship between producer $\mathrm{ABC}$ and their final customer through social activities, total profits of the dairy company, and the return of the goods issue of the customer. Thus, the authors suggested that further research might extend to different relationships between manufacturers and stakeholders based on CSR activities and SCM nexus. Considering the relationship between manufacturers and suppliers, the linkage effect between the dairy company and retailers in the dairy supply chain of an emerging economy is a promising idea for other scholars. Moreover, aiming to reduce their holding costs and enhance financial benefits, this proposed model could be conducted in various sectors to broaden and enrich the knowledge of the CSR initiatives' usefulness.

Author Contributions: M.-H.D. and Y.-F.H. developed conceptualization; methodology was developed by M.-W.W. and T.-S.C.; data curation and resources were undertaken by M.-H.D. and T.-S.C.; Y.-F.H. and M.-W.W. analyzed the data; wrote the manuscript, M.-H.D., M.-W.W., and T.-S.C.; writing-review and editing, T.-S.C., M.-H.D., and M.-W.W.; visualization, Y.-F.H.; supervision, Y.-F.H.; project administration, Y.-F.H. All authors have read and agreed to the published version of the manuscript.

Funding: The author's research was partially supported by the Ministry of Science and Technology of the Republic of China under Grant MOST 109-2622-H-324-001. Besides, this research was supported by the Ministry of Education, Taiwan, R. O. C. (Intelligence commerce and marketing craft the social practice model for the Prionailurus bengalensis and agricultural optimized regional revitalization in Chungliao).

Institutional Review Board Statement: Not applicable. 
Informed Consent Statement: Not applicable.

Data Availability Statement: Due to its proprietary nature <or ethical concerns $>$, supporting data cannot be made openly available.

Acknowledgments: The authors would like to thank the editor and anonymous reviewers for their valuable and constructive comments, which have led to a significant improvement in the manuscript.

Conflicts of Interest: The authors declare no conflict of interest.

\section{Appendix A}
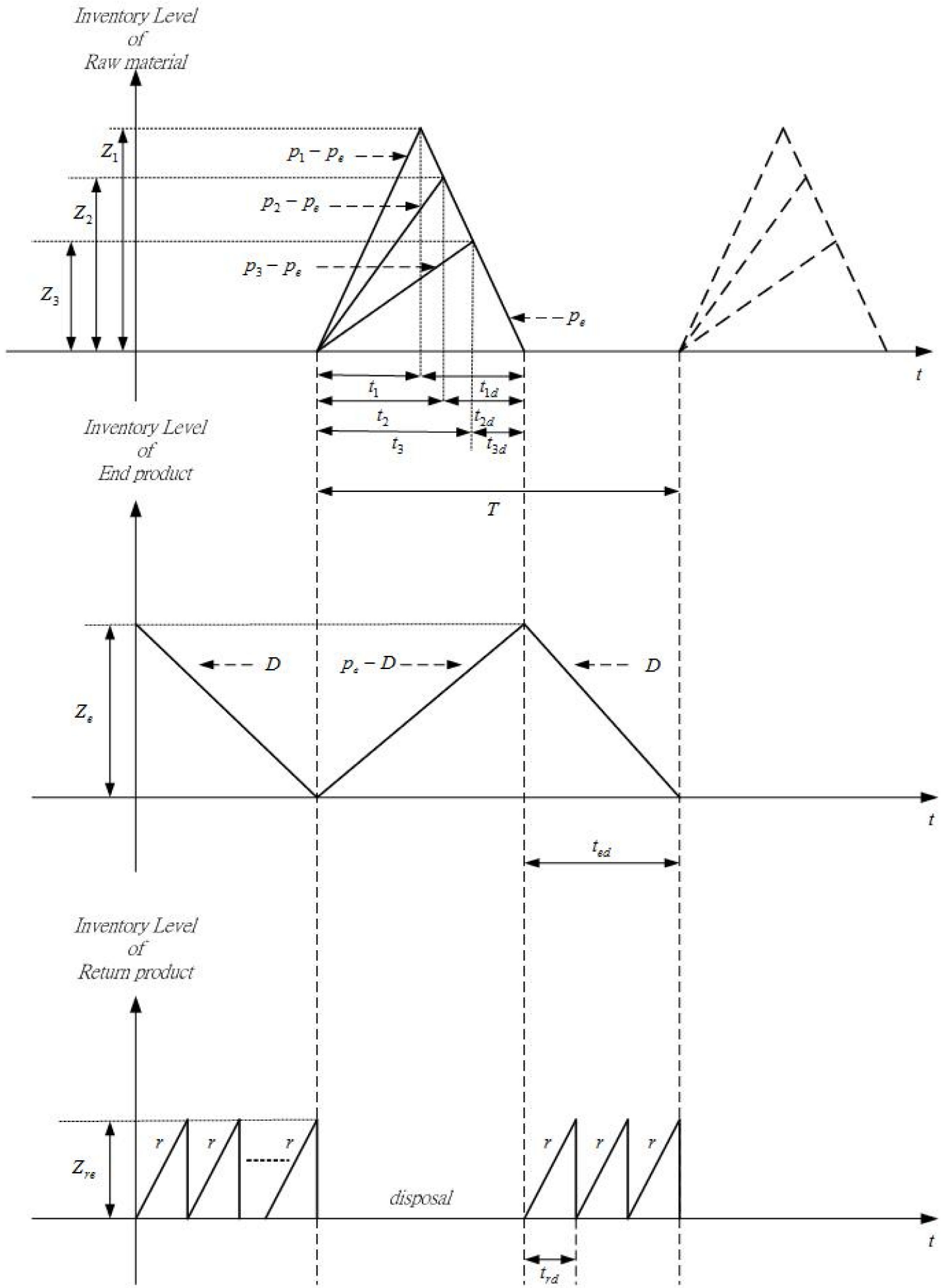

Figure A1. The graph of production system during time period $[0, T]$. 


\section{Appendix B}

Table A1. Effect of changes in various parameters of the model for application example.

\begin{tabular}{|c|c|c|c|c|c|}
\hline \multirow{2}{*}{ Parameter } & \multirow{2}{*}{$\begin{array}{c}\text { Change } \\
(\%)\end{array}$} & \multicolumn{4}{|c|}{ Optimal Solutions } \\
\hline & & $s^{*}$ & $t_{n}^{*}$ & $r^{*}$ & $T P\left(s^{*}, t_{n}^{*}, r^{*}\right)$ \\
\hline \multirow{5}{*}{$h_{1}$} & $-50 \%$ & 0.85486 & 0.15500 & 0.02282 & 287.395 \\
\hline & $-25 \%$ & 9.58942 & 0.49506 & 0.05962 & 287.395 \\
\hline & 0 & 9.58942 & 0.49538 & 0.05957 & 287.392 \\
\hline & $25 \%$ & 9.58943 & 0.49572 & 0.05954 & 287.389 \\
\hline & $50 \%$ & 9.58944 & 0.49605 & 0.05950 & 287.386 \\
\hline \multirow{5}{*}{$h_{2}$} & $-50 \%$ & 9.58939 & 0.49401 & 0.05975 & 287.404 \\
\hline & $-25 \%$ & 9.58941 & 0.49470 & 0.05966 & 287.398 \\
\hline & 0 & 9.58942 & 0.49538 & 0.05957 & 287.392 \\
\hline & $25 \%$ & 9.58944 & 0.49608 & 0.05950 & 287.386 \\
\hline & $50 \%$ & 9.58946 & 0.49678 & 0.05941 & 287.380 \\
\hline \multirow{5}{*}{$h_{3}$} & $-50 \%$ & 9.58883 & 0.47072 & 0.06271 & 287.627 \\
\hline & $-25 \%$ & 9.58977 & 0.50912 & 0.06115 & 287.506 \\
\hline & 0 & 9.58942 & 0.49538 & 0.05957 & 287.392 \\
\hline & $25 \%$ & 9.58977 & 0.50912 & 0.05797 & 287.283 \\
\hline & $50 \%$ & 9.59015 & 0.52394 & 0.05633 & 287.181 \\
\hline \multirow{5}{*}{$h_{e}$} & $-50 \%$ & 9.59251 & 0.85894 & 0.03436 & 289.676 \\
\hline & $-25 \%$ & 9.59027 & 0.61039 & 0.04835 & 288.211 \\
\hline & 0 & 9.58942 & 0.49538 & 0.05957 & 287.392 \\
\hline & $25 \%$ & 9.58898 & 0.42676 & 0.06916 & 286.836 \\
\hline & $50 \%$ & 9.58872 & 0.38024 & 0.07762 & 286.421 \\
\hline \multirow{5}{*}{$\theta_{1}$} & $-50 \%$ & 9.58942 & 0.49535 & 0.05959 & 287.393 \\
\hline & $-25 \%$ & 9.58943 & 0.49537 & 0.05958 & 287.392 \\
\hline & 0 & 9.58943 & 0.49538 & 0.05957 & 287.392 \\
\hline & $25 \%$ & 9.58944 & 0.49541 & 0.05957 & 287.391 \\
\hline & $50 \%$ & 9.58944 & 0.49543 & 0.05957 & 287.391 \\
\hline \multirow{5}{*}{$\theta_{2}$} & $-50 \%$ & 9.58942 & 0.49533 & 0.05958 & 287.393 \\
\hline & $-25 \%$ & 9.58943 & 0.49536 & 0.05958 & 287.392 \\
\hline & 0 & 9.58943 & 0.49538 & 0.05957 & 287.392 \\
\hline & $25 \%$ & 9.58943 & 0.49542 & 0.05957 & 287.391 \\
\hline & $50 \%$ & 9.58943 & 0.49545 & 0.05957 & 287.391 \\
\hline \multirow{5}{*}{$\theta_{3}$} & $-50 \%$ & 9.58942 & 0.49535 & 0.05959 & 287.393 \\
\hline & $-25 \%$ & 9.58943 & 0.49537 & 0.05958 & 287.392 \\
\hline & 0 & 9.58943 & 0.49538 & 0.05957 & 287.392 \\
\hline & $25 \%$ & 9.58943 & 0.49541 & 0.05957 & 287.391 \\
\hline & $50 \%$ & 9.58943 & 0.49543 & 0.05957 & 287.391 \\
\hline \multirow{5}{*}{$\theta_{e}$} & $-50 \%$ & 9.58907 & 0.48082 & 0.04808 & 287.643 \\
\hline & $-25 \%$ & 9.58925 & 0.48806 & 0.04880 & 287.517 \\
\hline & 0 & 9.58943 & 0.49538 & 0.05957 & 287.392 \\
\hline & $25 \%$ & 9.58961 & 0.51027 & 0.05870 & 287.269 \\
\hline & $50 \%$ & 9.58981 & 0.51028 & 0.05784 & 287.148 \\
\hline \multirow{5}{*}{$d_{1}$} & $-50 \%$ & 9.58942 & 0.49535 & 0.05959 & 287.391 \\
\hline & $-25 \%$ & 9.58943 & 0.49536 & 0.05958 & 287.391 \\
\hline & 0 & 9.58943 & 0.49538 & 0.05957 & 287.392 \\
\hline & $25 \%$ & 9.58943 & 0.49541 & 0.05957 & 287.392 \\
\hline & $50 \%$ & 9.58943 & 0.49543 & 0.05957 & 287.393 \\
\hline \multirow{5}{*}{$d_{2}$} & $-50 \%$ & 9.58942 & 0.49533 & 0.05959 & 287.391 \\
\hline & $-25 \%$ & 9.58943 & 0.49536 & 0.05958 & 287.391 \\
\hline & 0 & 9.58943 & 0.49538 & 0.05957 & 287.391 \\
\hline & $25 \%$ & 9.58943 & 0.49542 & 0.05957 & 287.392 \\
\hline & $50 \%$ & 9.58943 & 0.49545 & 0.05957 & 287.393 \\
\hline
\end{tabular}


Table A1. Cont.

\begin{tabular}{|c|c|c|c|c|c|}
\hline \multirow{2}{*}{ Parameter } & \multirow{2}{*}{$\begin{array}{c}\text { Change } \\
(\%)\end{array}$} & \multicolumn{4}{|c|}{ Optimal Solutions } \\
\hline & & $s^{*}$ & $t_{n}^{*}$ & $r^{*}$ & $T P\left(s^{*}, t_{n}^{*}, r^{*}\right)$ \\
\hline \multirow{5}{*}{$d_{3}$} & $-50 \%$ & 9.58942 & 0.49535 & 0.05959 & 287.391 \\
\hline & $-25 \%$ & 9.58943 & 0.49536 & 0.05958 & 287.391 \\
\hline & 0 & 9.58943 & 0.49538 & 0.05957 & 287.391 \\
\hline & $25 \%$ & 9.58943 & 0.49541 & 0.05957 & 287.392 \\
\hline & $50 \%$ & 9.58943 & 0.49543 & 0.05957 & 287.393 \\
\hline \multirow{5}{*}{$d_{e}$} & $-50 \%$ & 9.58943 & 0.49535 & 0.05959 & 287.391 \\
\hline & $-25 \%$ & 9.58943 & 0.49537 & 0.05958 & 287.391 \\
\hline & 0 & 9.58943 & 0.49538 & 0.05958 & 287.391 \\
\hline & $25 \%$ & 9.58943 & 0.49541 & 0.05958 & 287.391 \\
\hline & $50 \%$ & 9.58943 & 0.49543 & 0.05957 & 287.391 \\
\hline \multirow{5}{*}{$\beta_{0}$} & $-50 \%$ & 9.58907 & 0.48082 & 0.02282 & 287.643 \\
\hline & $-25 \%$ & 9.58925 & 0.48806 & 0.05962 & 287.517 \\
\hline & 0 & 9.58943 & 0.49538 & 0.05958 & 287.391 \\
\hline & $25 \%$ & 9.58961 & 0.50279 & 0.06047 & 287.269 \\
\hline & $50 \%$ & 9.58981 & 0.51027 & 0.06138 & 287.148 \\
\hline \multirow{5}{*}{$\beta_{1}$} & $-50 \%$ & 9.58942 & 0.49495 & 0.05963 & 287.399 \\
\hline & $-25 \%$ & 9.58942 & 0.49516 & 0.05960 & 287396 \\
\hline & 0 & 9.58943 & 0.49538 & 0.05958 & 287.391 \\
\hline & $25 \%$ & 9.58943 & 0.49561 & 0.05955 & 287.388 \\
\hline & $50 \%$ & 9.58944 & 0.49583 & 0.05953 & 287.384 \\
\hline \multirow{5}{*}{$\beta_{2}$} & $-50 \%$ & 9.58858 & 0.45958 & 0.06422 & 288.035 \\
\hline & $-25 \%$ & 9.58899 & 0.47723 & 0.06185 & 287.707 \\
\hline & 0 & 9.58943 & 0.49538 & 0.05958 & 287.391 \\
\hline & $25 \%$ & 9.58989 & 0.51405 & 0.05742 & 287.088 \\
\hline & $50 \%$ & 9.59039 & 0.53319 & 0.05536 & 286.795 \\
\hline
\end{tabular}

\section{References}

1. Gangi, F.; Mustilli, M.; Varrone, N. The impact of corporate social responsibility (CSR) knowledge on corporate financial performance: Evidence from the European banking industry. J. Knowl. Manag. 2019, 23, 110-134. [CrossRef]

2. Do, M.-H.; Huang, Y.-F.; Do, T.-N. The effect of total quality management-enabling factors on corporate social responsibility and business performance: Evidence from Vietnamese coffee firms. Benchmarking Ann. Int. J. 2020. [CrossRef]

3. Sharabati, A.A.A. Effect of corporate social responsibility on Jordan pharmaceutical industry's business performance. Soc. Responsib. J. 2018, 14, 566-583. [CrossRef]

4. Rhou, Y.; Singal, M.; Koh, Y. CSR and financial performance: The role of CSR awareness in the restaurant industry. Int. J. Hosp. Manag. 2016, 57, 30-39. [CrossRef]

5. Kong, D.; Shi, L.; Yang, Z. Product recalls, corporate social responsibility, and firm value: Evidence from the Chinese food industry. Food Policy 2019, 83, 60-69. [CrossRef]

6. Jamali, D.; Karam, C. Corporate Social Responsibility in Developing Countries as an Emerging Field of Study. Int. J. Manag. Rev. 2016, 20, 32-61. [CrossRef]

7. Carroll, A.B. Carroll's pyramid of CSR: Taking another look. Int. J. Corp. Soc. Responsib. 2016, 1, 1-8. [CrossRef]

8. Hategan, C.D.; Sirghi, N.; Curea-Pitorac, R.I.; Hategan, V.P. Doing well or doing good: The relationship between corporate social responsibility and profit in Romanian companies. Sustainability 2018, 10, 1041. [CrossRef]

9. Maqbool, S.; Zameer, M.N. Corporate social responsibility and financial performance: An empirical analysis of Indian banks. Futur. Bus. J. 2018, 4, 84-93. [CrossRef]

10. Nollet, J.; Filis, G.; Mitrokostas, E. Corporate social responsibility and financial performance: A non-linear and disaggregated approach. Econ. Model. 2016, 52, 400-407. [CrossRef]

11. Huang, Y.F.; Do, M.H.; Kumar, V. Consumers' perception on corporate social responsibility: Evidence from Vietnam. Corp. Soc. Responsib. Environ. Manag. 2019, 26, 1272-1284. [CrossRef]

12. Das, D. Sustainable supply chain management in Indian organisations: An empirical investigation. Int. J. Prod. Res. 2018, 56, 5776-5794. [CrossRef]

13. Heinberg, M.; Ozkaya, H.E.; Taube, M. Do corporate image and reputation drive brand equity in India and China?-Similarities and differences. J. Bus. Res. 2018, 86, 259-268. [CrossRef] 
14. Khosroshahi, H.; Rasti-Barzoki, M.; Hejazi, S.R. A game theoretic approach for pricing decisions considering CSR and a new consumer satisfaction index using transparency-dependent demand in sustainable supply chains. J. Clean. Prod. 2019, 208, 1065-1080. [CrossRef]

15. Bisogno, M. Corporate Social Responsibility and Supply Chains: Contribution to the Sustainability of Well-being. Agric. Agric. Sci. Procedia 2016, 8, 441-448. [CrossRef]

16. Hsu, S.Y.; Chang, C.C.; Lin, T.T. Triple bottom line model and food safety in organic food and conventional food in affecting perceived value and purchase intentions. Br. Food J. 2019, 121, 333-346. [CrossRef]

17. Pino, G.; Amatulli, C.; De Angelis, M.; Peluso, A.M. The influence of corporate social responsibility on consumers' attitudes and intentions toward genetically modified foods: Evidence from Italy. J. Clean. Prod. 2016, 112, 2861-2869. [CrossRef]

18. Sodhi, M.M.S.; Tang, C.S. Corporate social sustainability in supply chains: A thematic analysis of the literature. Int. J. Prod. Res. 2018, 56, 882-901. [CrossRef]

19. Zhang, M.; Tse, Y.K.; Doherty, B.; Li, S.; Akhtar, P. Sustainable supply chain management: Confirmation of a higher-order model. Resour. Conserv. Recycl. 2018, 128, 206-221. [CrossRef]

20. Sarkar, B.; Omair, M.; Choi, S.B. A multi-objective optimization of energy, economic, and carbon emission in a production model under sustainable supply chain management. Appl. Sci. 2018, 8, 1744. [CrossRef]

21. Feng, Y.; Zhu, Q.; Lai, K.H. Corporate social responsibility for supply chain management: A literature review and bibliometric analysis. J. Clean. Prod. 2017, 158, 296-307. [CrossRef]

22. Liu, Y.; Quan, B.T.; Xu, Q.; Forrest, J.Y.L. Corporate social responsibility and decision analysis in a supply chain through government subsidy. J. Clean. Prod. 2019, 208, 436-447. [CrossRef]

23. Ding, H.; Fu, Y.; Zheng, L.; Yan, Z. Determinants of the competitive advantage of dairy supply chains: Evidence from the Chinese dairy industry. Int. J. Prod. Econ. 2019, 209, 360-373. [CrossRef]

24. Chen, Y.S.; Chiu, S.C.; Lin, S.; Wu, K.H. Corporate social responsibility and income smoothing: Supply chain perspectives. J. Bus. Res. 2019, 97, 76-93. [CrossRef]

25. Wu, Y.; Li, H.; Gou, Q.; Gu, J. Supply chain models with corporate social responsibility. Int. J. Prod. Res. 2017, 55, 6732-6759. [CrossRef]

26. Tan, A.; Ngan, P.T. A proposed framework model for dairy supply chain traceability. Sustain. Futur. 2020, 2, 100034. [CrossRef]

27. Svensson, G.; Ferro, C.; Høgevold, N.; Padin, C.; Carlos Sosa Varela, J.; Sarstedt, M. Framing the triple bottom line approach: Direct and mediation effects between economic, social and environmental elements. J. Clean. Prod. 2018, 197, 972-991. [CrossRef]

28. Gómez-Luciano, C.A.; Rondón Domínguez, F.R.; González-Andrés, F.; Urbano López De Meneses, B. Sustainable supply chain management: Contributions of supplies markets. J. Clean. Prod. 2018, 184, 311-320. [CrossRef]

29. Ghadimi, P.; Azadnia, A.H.; Heavey, C.; Dolgui, A.; Can, B. A review on the buyer-supplier dyad relationships in sustainable procurement context: Past, present and future. Int. J. Prod. Res. 2016, 54, 1443-1462. [CrossRef]

30. Khalid, R.U.; Seuring, S.; Beske, P.; Land, A.; Yawar, S.A.; Wagner, R. Putting sustainable supply chain management into base of the pyramid research. Supply Chain Manag. 2015, 20, 681-696. [CrossRef]

31. Zhong, R.; Xu, X.; Wang, L. Food supply chain management: Systems, implementations, and future research. Ind. Manag. Data Syst. 2017, 117, 2085-2114. [CrossRef]

32. Scalia, G.L.; Settanni, L.; Micale, R.; Enea, M. Predictive shelf life model based on RF technology for improving the management of food supply chain: A case study. Int. J. RF Technol. Res. Appl. 2016, 7, 31-42. [CrossRef]

33. Chkanikova, O.; Mont, O. Corporate supply chain responsibility: Drivers and barriers for sustainable food retailing. Corp. Soc. Responsib. Environ. Manag. 2015, 22, 65-82. [CrossRef]

34. Prakash, G. Review of the food processing supply chain literature: A UK, India bilateral context. J. Adv. Manag. Res. 2018, 15, 457-479. [CrossRef]

35. Gouda, S.K.; Saranga, H. Sustainable supply chains for supply chain sustainability: Impact of sustainability efforts on supply chain risk. Int. J. Prod. Res. 2018, 56, 5820-5835. [CrossRef]

36. Golini, R.; Moretto, A.; Caniato, F.; Caridi, M.; Kalchschmidt, M. Developing sustainability in the Italian meat supply chain: An empirical investigation. Int. J. Prod. Res. 2017, 55, 1183-1209. [CrossRef]

37. Chen, X.; Wu, S.; Wang, X.; Li, D. Optimal pricing strategy for the perishable food supply chain. Int. J. Prod. Res. 2019, 57, 2755-2768. [CrossRef]

38. Dries, L.; Swinnen, J.F.M. The impact of interfirm relationships on investment: Evidence from the Polish dairy sector. Food Policy 2010, 35, 121-129. [CrossRef]

39. Dervillé, M.; Allaire, G. Change of competition regime and regional innovative capacities: Evidence from dairy restructuring in France. Food Policy 2014, 49, 347-360. [CrossRef]

40. Glover, J.L.; Champion, D.; Daniels, K.J.; Dainty, A.J.D. An Institutional Theory perspective on sustainable practices across the dairy supply chain. Int. J. Prod. Econ. 2014, 152, 102-111. [CrossRef]

41. Augustin, M.A.; Udabage, P.; Juliano, P.; Clarke, P.T. Towards a more sustainable dairy industry: Integration across the farmfactory interface and the dairy factory of the future. Int. Dairy J. 2013, 31, 2-11. [CrossRef]

42. Krishnamoorthi, C.; Panayappan, S. An EPQ model for an imperfect production system with rework and shortages. Int. J. Oper. Res. 2013, 17, 104-123. [CrossRef] 
43. Wee, H.M.; Wang, W.T.; Cárdenas-Barrón, L.E. An alternative analysis and solution procedure for the EPQ. model with rework process at a single-stage manufacturing system with planned backorders. Comput. Ind. Eng. 2013, 64, 748-755. [CrossRef]

44. Teng, J.T.; Lou, K.R.; Wang, L. Optimal trade credit and lot size policies in economic production quantity models with learning curve production costs. Int. J. Prod. Econ. 2014, 155, 318-323. [CrossRef]

45. Wu, J.; Teng, J.T.; Skouri, K. Optimal inventory policies for deteriorating items with trapezoidal-type demand patterns and maximum lifetimes under upstream and downstream trade credits. Ann. Oper. Res. 2018, 264, 459-476. [CrossRef]

46. Ma, P.; Wang, H.; Shang, J. Contract design for two-stage supply chain coordination: Integrating manufacturer-quality and retailer-marketing efforts. Int. J. Prod. Econ. 2013, 146, 745-755. [CrossRef]

47. Chang, H.J.; Su, R.H.; Yang, C.-T.; Weng, M.W. An economic manufacturing quantity model for a two-stage assembly system with imperfect processes and variable production rate. Comput. Ind. Eng. 2012, 63, 285-293. [CrossRef]

48. Sabbaghnia, A.; Taleizadeh, A.A. Quality, buyback and technology licensing considerations in a two-period manufacturingremanufacturing system: A closed-loop and sustainable supply chain. Int. J. Syst. Sci. Oper. Logist. 2020, 1-19. [CrossRef]

49. Wensing, T.; Kuhn, H. Analysis of a multi-component periodic review inventory system in an assembly environment. OR Spectr. 2013, 35, 107-126. [CrossRef]

50. Yao, Z.; Lee, L.H.; Chew, E.P.; Hsu, V.N.; Jaruphongsa, W. Dual-channel component replenishment problem in an assemble-toorder system. IIE Trans. 2013, 45, 229-243. [CrossRef]

51. Keizer, M.C.A.O.; Teunter, R.H.; Veldman, J. Joint condition-based maintenance and inventory optimization for systems with multiple components. Eur. J. Oper. Res. 2017, 257, 209-222. [CrossRef]

52. Cheng, G.Q.; Zhou, B.H.; Li, L. Joint optimization of lot sizing and condition-based maintenance for multi-component production systems. Comput. Ind. Eng. 2017, 110, 538-549. [CrossRef]

53. Modak, N.M.; Kazemi, N.; Cárdenas-Barrón, L.E. Investigating structure of a two-echelon closed-loop supply chain using social work donation as a Corporate Social Responsibility practice. Int. J. Prod. Econ. 2019, 207, 19-33. [CrossRef]

54. Gupta, M.; Mohanty, B.K. Multi-stage multi-objective production planning using linguistic and numeric data-a fuzzy integer programming model. Comput. Ind. Eng. 2015, 87, 454-464. [CrossRef]

55. Dey, B.K.; Sarkar, B.; Pareek, S. A two-echelon supply chain management with setup time and cost reduction, quality improvement and variable production rate. Mathematics 2019, 7,328. [CrossRef]

56. Nematollahi, M.; Hosseini-Motlagh, S.M.; Heydari, J. Coordination of social responsibility and order quantity in a two-echelon supply chain: A collaborative decision-making perspective. Int. J. Prod. Econ. 2017, 184, 107-121. [CrossRef]

57. Jokar, A.; Hosseini-Motlagh, S.M. Simultaneous coordination of order quantity and corporate social responsibility in a twoEchelon supply chain: A combined contract approach. J. Oper. Res. Soc. 2020, 71, 69-84. [CrossRef]

58. The World Bank Group (WB) Overview Vietnam. Available online: https://www.worldbank.org/en/country/vietnam/overview (accessed on 18 December 2020).

59. Do, T.N.; Kumar, V.; Do, M.H. Prioritize the key parameters of Vietnamese coffee industries for sustainability. Int. J. Product. Perform. Manag. 2020, 69, 1153-1176. [CrossRef]

60. Hosseini-Motlagh, S.-M.; Nematollahi, M.; Nouri, M. Coordination of green quality and green warranty decisions in a two-echelon competitive supply chain with substitutable products. J. Clean. Prod. 2018, 196, 961-984. [CrossRef]

61. Giri, B.C.; Yun, W.Y.; Dohi, T. Optimal design of unreliable production-inventory systems with variable production rate. Eur. J. Oper. Res. 2005, 162, 372-386. [CrossRef]

62. Savaskan, R.C.; Bhattacharya, S.; Wassenhove, L.N. van Closed-Loop Supply Chain Models with Product Remanufacturing. Manage. Sci. 2004, 50, 239-252. [CrossRef]

63. VNR500 Vietnam Report top 500 Company. Available online: http://www.vnr500.com.vn/Nganh-nghe/San-xuat-kinh-doanhthuc-pham-che-bien-Post/26.html (accessed on 12 March 2020). 